\title{
PENINGKATAN KETERAMPILAN MENYIMAK TEKS PROSEDUR PADA SISWA KELAS VII DI SMPN 6 SINGINGI HILIR MELALUI STRATEGI GUIDED NOTE TAKING
}

\author{
Oleh \\ Deliana \\ SMPN 6 Singingi Hilir \\ Email: deliana111168@gmail.com
}

\begin{tabular}{ll}
\hline \multicolumn{2}{l}{ Article History } \\
\hline Received & : January 2020 \\
Accepted & :February \\
& 2020 \\
Published & : March 2020
\end{tabular}

\section{Keywords}

Keterampilan menyimak, teks prosedur, guided note taking

\begin{abstract}
This study aims to improve the skills of listening to procedural texts in grade VII students at SMPN 6 Singingi Hilir through the Guided Note Taking strategy. This type of research is classroom action research using two cycles and four stages, namely planning, action, observation, and evaluation. Research instruments, namely teacher and student observation sheets and performance tests in the form of the results of the test of listening to the text of the procedure.
\end{abstract}

The study revealed that the initial test results of the average value of students was 54.4, the first cycle the average value of students was 77.53 and in the second cycle the average value of listening to students was 90.3. Test results show an increase. From the results of the study revealed that the evaluation results indicate the success of teachers in learning is determined by planned activities with an improved change between the implementation of the activities of cycle I and II. It was concluded that learning to listen to the text of the procedure with the guided note taking strategy could improve the listening skills of the eighth grade students at SMPN 6 Singingi Hilir. 
perencanaan, tindakan, observasi, dan evaluasi. Instrumen penelitian, yaitu lembar observasi guru dan siswa serta tes unjuk kerja berupa hasil tes keterampilan menyimak teks prosedur.

Penelitian mengungkapkan bahwa hasil tes awal nilai rata-rata siswa adalah 54,4, siklus I nilai rata-rata siswa adalah 77,53 dan pada siklus II nilai rata-rata menyimak siswa adalah 90,3. Hasil tes menunjukkan adanya peningkatan. Dari hasil penelitian terungkap bahwa hasil evaluasi menunjukkan keberhasilan guru dalam pembelajaran ditentukan oleh kegiatan yang direncanakan dengan adanya perubahan yang membaik antara pelaksanaan kegiatan siklus I dan II. Disimpulkan bahwa pembelajaran menyimak teks prosedur dengan strategi guided note taking dapat meningkatkan keterampilan menyimak siswa keas VII di SMPN 6 Singingi Hilir. 


\section{A. Pendahuluan}

Mata pelajaran bahasa Indonesia merupakan salah satu yang diajarkan di sekolah baik di tingkat Sekolah Dasar (SD), Sekolah Menengah Pertama (SMP) maupun Sekolah Menengah Atas (SMA)/sederajat. Pada pembelajaran bahasa Indonesia terdapat empat keterampilan yang diajarkan oleh guru, yaitu: (1) menyimak, (2) berbicara, (3) membaca, dan (4) menulis. Salah satu keterampilan yang harus dikuasai adalah keterampilan menyimak. Menurut Tarigan (2008: 4) menyimak adalah suatu proses kegiatan mendengarkan lambang-lambang lisan dengan penuh perhatian, pemahaman, apresiasi, serta interpretasi untuk memperoleh informasi, menangkap isi atau pesan serta memahami makna komunikasi yang telah disampaikan oleh sang pembicara melalui ujaran atau bahasa lisan. Selanjutnya, Hardini \& Puspitasari (2012:184) menyatakan bahwa keterampilan menyimak adalah satu bentuk keterampilan berbahasa yang bersifat reseptif.

Dalam pembelajaran keterampilan menyimak salah satunya terdapat pada materi keterampilan menyimak teks prosedur yang terdapat pada siswa kelas VII. Teks prosedur merupakan teks yang berisi tujuan dan langkah-langkah yang harus diikuti agar suatu pekerjaan dapat dilakukan (Kemendikbud, 2013 : 84). Langkah-langkah tersebut, biasanya tidak dapat dibolak-balik. Saat pembelajaran teks prosedur, siswa mengeksplorasi bahasa dalam bentuk prosedur yang akan digunakan untuk dapat mengikuti segala proses dalam kehidupan masyarakat.

Menurut Mahsun (2014: 30) teks prosedur adalah teks yang bertujuan untuk memberikan pengarahan atau pengajaran tentang langkah-langkah sesuatu yang telah ditentukan. Teks posedur berisikan suatu pengamatan ataupun percobaan, lebih lanjut Mahsun menjelaskan bahwa teks prosedur memiliki struktur berpikir: judul, tujuan, daftar bahan, urutan tahapan pelaksanaan, pengamatan dan simpulan.

Dalam upaya meningkatkan hasil belajar siswa pada keterampilan menyimak teks prosedur, guru dapat menggunakan berbagai strategi pembelajaran yang inovatif. Salah satu strategi pembelajaran yang dapat diterapkan, yaitu strategi guided note taking. Guided Note Taking (Zaini, 2011: 
35), adalah strategi yang menuntut seorang guru untuk menyiapkan suatu bagan atau skema (handout) sebagai media yang dapat membantu siswa dalam membuat catatan, dalam hal ini pembelajaran menyimak berita. Tujuan strategi Guided Note Taking adalah agar strategi yang dikembangkan oleh guru mendapat perhatian siswa, terutama pada kelas yang jumlah siswanya cukup banyak.

\section{Adapun langkah-langkah Strategi} Guided Note Taking (Zaini, 2011: 35-36), yaitu: (1) beri siswa panduan dalam bentuk bagan/skema yang berisi ringkasan poinpoin utama dari materi berita yang akan disimak; (2) kosongkan sebagian dari poinpoin yang dianggap penting sehingga akan terdapat ruang kosong dalam panduan tersebut; (3) bagikan bahan ajar (handout) yang dibuat kepada siswa, kemudian beri siswa penjelasan; (4) siswa mulai menyimak berita; (5) setelah selesai menyimak berita mintalah salah satu siswa untuk membacakan hasil simakan; dan (6) beri klarifikasi.

\section{B. Metode Penelitian}

Jenis penelitian ini adalah penelitian tindakan dengan metode kualitatif dan kuantitatif. Menurut Arikunto (2006:4) penelitian tindakan kelas merupakan suatu pencermatan terhadap kegiatan belajar berupa sebuah tindakan yang sengaja dimunculkan dan terjadi dalam sebuah kelas secara bersama (Putri \& Elvina, 2019). Selanjutnya, Susilo (2009:16) mengatakan bahwa penelitian tindakan kelas adalah penelitian yang dilakukan oleh guru di kelas atau disekolah tempat mengajar, dengan penekanan pada penyempurnaan atau peningkatan praktik dan proses dalam pembelajaran.

Penelitian ini menggunakan dua siklus dengan empat langkah utama dalam penelitian tindakan yakni: (1) perencanaan tindakan (planning), (2) penerapan tindakan (action), (3) mengobservasi dan mengevaluasi proses dan hasil tindakan (observation and evaluation), dan (4) melakukan refleksi (reflecting), dan seterusnya sampai perbaikan atau peningkatan yang diharapkan tercapai (kriteria keberhasilan) (Arikunto, 2006:104. Subjek penelitian adalah siswa kelas VII 
yang berjumlah 26 orang yang terdaftar di SMPN 6 Singingi Hilir.

\section{Hasil Penelitian dan Pembahasan}

\section{Hasil Penelitian}

a) Prasiklus

Berdasarkan prasiklus diperoleh data keterampilan menyimak teks prosedur bahwa siswa tidak memahami teks prosedur dengan baik. Berikut penjelasan nilai awal siswa kelas VII dalam menyimak teks prosedur.

Diperoleh rata-rata hitung (M) sebesar 54,4. Berdasarkan rata-rata hitung (M) yang diperoleh dapat disimpulkan bahwa keterampilan menyimak siswa kelas VII di SMPN 6 Singingi Hilir berada pada kategori hampir cukup karena berada pada rentang $46-55 \%$ pada skala 10 .

Langkah selanjutnya adalah meng klasifikasikan keterampilan menyimak teks prosedur siswa kelas VII di SMPN 6 Singingi Hilir berdasarkan skala 10 dapat dikelompokkan menjadi empat yaitu: (1) klasifikasi kurang cukup sebanyak 6 orang (20\%), (2) klasifikasi hampir cukup sebanyak 10 orang (38\%), (3) klasifikasi lebih dari cukup sebanyak 7 orang $(30 \%)$, dan (4) klasifikasi baik sebanyak 3 orang $(12 \%)$

\section{b) Siklus I}

Dari data di atas dapat dilihat bahwa rata-rata hasil menyimak teks prosedur siswa sudah baik pada siklus I yaitu, berdasarkan nilai terendah adalah 50 dan nilai tertinggi adalah 100. Namun, ketuntasan siswa masih tergolong cukup, yaitu siswa yang tuntas sebanyak 15 orang $(73,3 \%)$ dan yang tidak tuntas sebanyak 11 orang $(26,7 \%)$. Secara umum perlu dilakukan tindakan pada keterampilan menyimak teks prosedur siswa pada siklus II karena ketuntasan belum mencapai $80 \%$. langkah-langkah atau aktivitas belajar mengajar oleh guru belum terlaksana dengan baik atau sempurna. Maka, masih perlu dilakukan perbaikan untuk mendapatkan hasil yang lebih memuaskan baik dalam hal (1) perencanaan pembelajaran, (2) pelaksanaan pembelajaran, (3) evaluasi pembelajaran, (4) hasil pemahaman siswa terhadap pembelajaran menyimak teks prosedur. Berdasarkan kekurangan yang terjadi pada siklus I tersebut, maka perlu dilakukan 
perbaikan untuk mendapatkan hasil yang lebih memuaskan. Terutama untuk meningkatkan,

pembelajaran,

perencanaan

pelaksanaan

pembelajaran, (3) evaluasi pembelajaran, dan (4) hasil pemahaman siswa terhadap pembelajaran.

c) Siklus II

Dapat dilihat bahwa rata-rata hasil menyimak teks prosedur siswa sudah baik pada siklus II yaitu, berdasarkan nilai terendah adalah 66,6 dan nilai tertinggi adalah 100. Ketuntasan siswa sudah tergolong sangat baik, yaitu siswa yang tuntas sebanyak 22 orang $(84,6 \%)$ dan yang tidak tuntas sebanyak 4 orang $(15,4 \%)$. Secara umum tidak perlu dilakukan tindakan pada keterampilan menyimak teks prosedur siswa pada siklus selanjutnya karena ketuntasan sudah mencapai $80 \%$.

\section{Pembahasan}

Setelah tingkat penguasaan menyimak teks prosedur diketahui, langkah selanjutnya adalah menafsirkan tingkat keterampilan menyimak teks prosedur siswa berdasarkan rata-rata hitung (M). Untuk keperluan data pada lampiran dimasukkan dalam tabel distribusi frekuensi berikut.

Tabel 1. Distribusi Frekuensi Keterampilan Menyimak Teks Prosedur Siswa Kelas VII di SMPN 6 Singingi HIlir pada Siklus I

\begin{tabular}{|c|c|c|c|c|}
\hline No. & F & X & FX & Keterangan \\
\hline 1 & 6 & 100 & 600 & Sempurna \\
2 & 9 & 83,3 & 749,7 & Baik \\
3 & 7 & 66,6 & 466,2 & $\begin{array}{c}\text { Lebih dari } \\
\text { cukup }\end{array}$ \\
4 & 4 & 50 & 200 & $\begin{array}{c}\text { Hampir } \\
\text { Cukup }\end{array}$ \\
\hline \multicolumn{3}{|c|}{$\sum F X$} & $2.015,9$ & \\
\hline
\end{tabular}

Diperoleh rata-rata hitung (M) sebesar 77,53. berdasarkan rata-rata hitung (M) yang diperoleh dapat disimpulkan bahwa tingkat keterampilan menyimak teks prosedur siswa kelas VII di SMPN 6 Singingi Hilir berada pada kategori baik karena berada pada rentang $76-85 \%$ pada skala 10.

Tingkat penguasaan menyimak teks prosedur diketahui, langkah selanjutnya adalah menafsirkan tingkat keterampilan menyimak teks prosedur siswa berdasarkan rata-rata hitung (M). Untuk keperluan data pada lampiran 
dimasukkan dalam tabel distribusi frekuensi berikut.

Tabel 2. Distribusi Frekuensi Keterampilan Menyimak Teks Prosedur Siswa Kelas VII di SMPN 6 Singingi HIlir pada Siklus II

\begin{tabular}{|c|c|c|c|c|}
\hline No. & $\mathbf{F}$ & $\mathbf{X}$ & FX & Keterangan \\
\hline 1 & 15 & 100 & 1.500 & Sempurna \\
\hline 2 & 7 & 83,3 & 583,1 & Baik \\
\hline 3 & 4 & 66,6 & 266,4 & $\begin{array}{l}\text { Lebih dari } \\
\text { cukup }\end{array}$ \\
\hline \multicolumn{3}{|c|}{$\sum F X$} & $2.349,5$ & \\
\hline
\end{tabular}

Dari data tabel tersebut diperoleh rata-rata hitung (M) sebesar 90,3. berdasarkan rata-rata hitung (M) yang diperoleh dapat disimpulkan bahwa tingkat keterampilan menyimak teks prosedur siswa kelas VII di SMPN 6 Singingi Hilir berada pada kategori baik sekali karena berada pada rentang 86-95\% pada skala 10 .

Langkah selanjutnya adalah mengklasifikasikan tingkat keterampilan menyimak teks prosedur siswa kelas VII di SMPN 6 Singingi Hilir berada pada skala 10 dapat dikelompokkan menjadi 3 yaitu: (1) Sempurna sebanyak 15 orang (58\%), (2) baik sebanyak 7 orang (27\%), dan (3) Klasifikasi lebih dari cukup sebanyak 4 orang (15\%). Berdasarkan data tabel diperoleh gambaran bahwa keterampilan menyimak teks prosedur siswa pada akhir siklus II meningkat dibandingkan siklus I.

\section{Simpulan dan Saran}

Pembelajaran menyimak teks prosedur dengan menggunakan strategi guided note taking dirancang dalam bentuk Rancangan Pelaksanaan Pembelajaran (RPP) yang disusun berdasarkan Kurikulum Tingkat Satuan Pendidikan. Proses pembelajaran menyimak teks prosedur dengan strategi guided note taking menggunakan empat tahap, yaitu perencanaan, tindakan, evaluasi, dan refleksi.

Penelitian mengungkapkan bahwa hasil tes awal nilai rata-rata siswa adalah 54,4 , siklus I nilai rata-rata siswa adalah 77,53 dan pada siklus II nilai rata-rata menyimak siswa adalah 90,3. Hasil tes menunjukkan adanya peningkatan. Dari hasil penelitian terungkap bahwa hasil evaluasi menunjukkan keberhasilan guru dalam pembelajaran ditentukan oleh kegiatan yang direncanakan dengan adanya 
perubahan yang membaik antara Susilo, 2009. Panduan Penelitian pelaksanaan kegiatan siklus I dan II. Tindakan Kelas. Yogyakarta: Pustaka Book Publisher.

Disimpulkan bahwa pembelajaran menyimak teks prosedur dengan strategi guided note taking dapat meningkatkan keterampilan menyimak siswa keas VII di SMPN 6 Singingi Hilir.

Zaini, Hisyam dkk. 2011. Strategi Pembelajaran Aktif. Yogyakarta: CTSD.

\section{Daftar Pustaka}

Arikunto, Suharsimi, dkk. 2006. Penelitian Tindakan Kelas. Jakarta: Bumi Aksara.

Depdiknas. 2013. Pedoman Umum Pengembangan Sistem Penilaian Hasil Belajar Berbasis Kompetensi Siswa Menengah Pertama (SMP). Jakarta: Depdiknas.

Hardini, I \& Puspitasari, D. 2012. Strategi Pembelajaran Terpadu (Teori, Konsep \& Implementasi). Yogyakarta: Familia.

Mahsun. 2014. Teks dalam Pembelajaran Bahasa Indonesia Kurikulum 2013. Jakarta: Rajawali Pers.

Putri, D., \& Elvina. (2019). Penerapan Metode Game's untuk Meningkatkan Karakter pada Siswa Sekolah Dasar. Jurnal Pendidikan Rokania, IV(3), 452-462. 